УДК 349.22

DOI https:/ / doi.org/10.32837 / yuv.v0i5.2016

\author{
М. Шадей, \\ аспірант кафедри трудового права \\ Національного юридичного університету імені Ярослава Мудрого
}

\title{
ДО ПИТАННЯ ЗАБОРОНИ ДИСКРИМІНАЦІЇ У СФЕРІ ПРАЦІ
}

Постановка проблеми. Проблема боротьби 3 дискримінацією та іiі проявами є досить актуальною для сучасної України. Відповідно до Конституції України та міжнародних зобов'язань, Україна зобов'язана протидіяти дискримінації в будь-якій формі, рівною мірою забезпечувати соціально-трудові права населення, Дискримінації 3 різним ступенем інтенсивності «пульсують» у духовній, соціальній, трудовій, економічній, політичній та іншій галузях соціального буття. Це свідчить про те, що боротьба з дискримінацією є загальноправовою проблемою.

Усунення проявів дискримінації у трудових відносинах є одним із важливих та першочергових пріоритетів діяльності міжнародних організацій, які з метою вирішення даної проблеми ухвалили низку нормативно-правових документів. Прагнення України до євроінтеграції зобов'язує нашу державу забезпечити відповідність національного законодавства міжнародним стандартам, зокрема i стандартам рівності у трудових правовідносинах. Варто зазначити, що Україна вже взяла на себе зобов'язання боротися із проявами дискримінації у сфері праці, коли ратифікувала основоположні міжнародно-правові документи із цього питання, основними серед яких є: Європейська соціальна хартія (переглянута в 1996 р.) та Хартія основних соціальних прав працівників (1989 р.), які є основоположними для кожної країни, яка прагне викоренити прояви дискримінації у своїй державі й із цією метою закріплює відповідні норми у вітчизняному законодавстві.

Актуальність дослідження. Проблеми дискримінації у сфері реалізації права на працю вивчали такі науковці, як: О. Антон, Н. Болотіна, М. Венедиктова, О. Гаврилюк, О. Процевський, В. Пузирний, О. Ярошенко. Але у зв'язку з гостротою й актуальністю на сучасному етапі розвитку та становлення України проблеми дискримінації у сфері реалізації права на працю набувають великого значення та потребують додаткових досліджень.

Метою статті $€$ дослідження окремих проблем дискримінації, що виникають у сфері реалізації права на працю.

Виклад основного матеріалу. Поява антидискримінаційного законодавства у сфері трудових відносин припадає на другу половину 40-х рр., коли держави, які приєдналися до Загальної декларації прав людини [1], відповідно до ст. 23 якої кожна людини має право на працю, на вільний вибір роботи, на справедливі та сприятливі умови праці та на захист від безробіття, почали додавати у свої конституції положення, що забороняли дискримінацію. У 60-70-х рр. у багатьох країнах ухвалюють спеціальні закони, спрямовані на боротьбу з дискримінацією. Сьогодні заборона дискримінації у сфері праці так або інакше закріплена в законодавстві всього цивілізованого світу [2, с. 54].

Найбільш розгорнутий перелік соціально-економічних, зокрема і трудових, 
прав індивідів на універсальному рівні міститься в Міжнародному пакті про економічні, соціальні та культурні права [3], у ч. 2 ст. 2 якого закріплено обов'язок усіх держав-учасниць гарантувати, що права, проголошені в ньому, забезпечуватимуться без будь-яких проявів дискримінації.

Конвенція Міжнародної організаціï праці (далі - МОП) № 111 «Про дискримінацію в галузі праці і занять» [4] покладає обов'язок на кожну державу - учасницю організації визначати та впроваджувати національну політику, спрямовану на заохочення методами, що відповідають національним умовам та практиці, рівності можливостей і ставлення до праці та занять із метою викорінення будьякої дискримінації. У ст. 1 Конвенції наведений перелік ознак, за якими може відбуватись дискримінація: (а) ознаки раси, кольору шкіри, статі, релігіі, політичних переконань, іноземного походження або соціального статусу; (б) будь-яка інша відмінність, недопущення або перевага, що призводить до знищення або порушення рівності можливостей або поводження в галузі праці та занять, що визначається будь-якою державою-учасницею на підставі консультацій із представниками роботодавців і профспілок та з іншими відповідними органами.

Не оминули проблеми дискримінаціï у сфері праці й Європу. Основна частина європейських трудоправових стандартів міститься в Європейській соціальній хартії (переглянутій) [5], яку інколи називають «Кодексом основних соціальних і трудових прав працівників». Україною не взято на себе зобов'язання тільки за двома статтями, що стосуються трудових прав: ст. 19 «Право трудящих-мігрантів і членів ї сімей на захист i допомогу» і ст. 25 «Право працівників на захист їх прав у випадку банкрутства їх роботодавця». За Хартією забороняється дискримінація за будь-якою підставою, зокрема статтю, расою, кольором шкіри, етнічним або соціальним походженням, генетичними характеристиками, мовою, релігією або віруванням, політичною або іншою думкою, приналежністю до національної меншини, майном, народженням, інвалідністю, віком, сексуальною орієнтацією.

Відповідно до ст. 13 Договору Європейського Союзу була розроблена й ухвалена стратегія з боротьби з дискримінацією, яка об'єднує: (1) директиву «Про реалізацію принципу рівного ставлення незалежно від расової або етнічної приналежності» Расова директива; (2) директиву «Про встановлення загальних умов рівного ставлення у сфері зайнятості і професійної діяльності» - Рамкова директива про зайнятість; (3) Програму дій із боротьби з дискримінацією.

Як бачимо, забезпечення рівності та недопущення дискримінації належать до основоположних міжнародних стандартів у царині праці. Водночас сьогодні в Україні почастішали прояви дискримінації у трудових та тісно пов'язаних із ними відносинах. Наслідками дискримінаційних дій роботодавців є порушення прав працівників, зниження рівня зайнятості окремих їх категорій. Найбільшу небезпеку несуть ті види дискримінаціï, які деформують основи державного й суспільного устрою, зокрема дискримінація за ознакою статі, раси, національності, релігійної приналежності. Активізація в даний час діяльності 3 боротьби 3 дискримінацією примусила гостро відчути необхідність розвитку процедурно-процесуального механізму в царині захисту трудових прав працівників. Ступінь наближеності тієї чи іншої держави до правового ідеалу визначається не тільки закріпленими в законах правами та свободами, а й розробленістю ефективних засобів і способів їх практичного здійснення та забезпечення.

Під час розгляду вказаної проблеми важливо визначитися 3 поняттям «дискримінація». Уведене в науковий обіг, це поняття зайняло свою 
нішу в низці інших політико-юридичних категорій. У соціальному світогляді дискримінація характеризується як явище, що має у своїй основі деформацію певного правового стану, можливість автономного розвитку в соціумі й базоване на виборі підстав диференціації винятково із суб'єктивних підстав. «Дискримінація» як одне $з$ найбільш популярних понять активно «експлуатоване» у вітчизняному науковому й публіцистичному оборотах. Водночас воно залишається у відриві від самого явища, поза належним і всебічним аналізом сутності одного з найбільш масових, здебільшого негативних, феноменів сучасної правової дійсності. Основний акцент сучасне правознавство робить на дослідженні форм прояву та причин цього явища [6, с. 167].

У Юридичному словнику Блека визначено дискримінацію як явище надання певних привілеїв групі, необгрунтовано обраної із загальної маси людей, що володіють таким же правом на дані привілеї, нездатність рівного звернення до ситуації, коли немає обгрунтованого розмежування для привілейованих і непривілейованих [7, с. 1511]. Якщо говорити про дискримінацію стосовно саме трудових відносин, то, наприклад, словник Канадського права визначає акт дискримінації як дію роботодавця, що несприятливо впливає на трудові відносини працівника в таких сферах, як просування по службі, вихід у відпустку, звільнення, страйк, зниження оплати, зміна робочого часу, оголошення догани [8, с. 237]. Словник термінів, пов'язаних із працевлаштуванням, говорить, що роботодавець може робити відмінності між працівниками на підставі продуктивності праці, здатностей до праці, але не на підставі критеріїв, заборонених законами про працю [9, с. 146].

Заборона дискримінації, як і будьяка законодавча заборона на вчинення певних дій, 3 необхідністю повинна бути підкріплена нормами, що передбачають заходи захисту порушеного права, забезпечені примусовою силою держави. Правове регулювання заборони дискримінації здійснюеться не тільки шляхом нормативного закріплення вказаного принципу в основних міжнародних i національних актах; установлення спеціальних заходів і способів, покликаних не допустити факти дискримінації; а й шляхом визначення способів захисту прав громадян від дискримінації в разі порушення конституційного принципу рівності. Наприклад, галузевим продовженням указаних принципів, які закріплені в ч. 1 ст. 21 та ст. 24 Конституції України, є гарантована законодавцем юридична рівність у можливості отримати та виконувати певну працю, а також мати належний відпочинок у ст. 21 Кодексу законів про працю (далі - КЗпП) України [10]. Крім того, національне трудове законодавство містить пряму норму, яка вказує на недопустимість будь-якого прямого або непрямого обмеження прав чи встановлення прямих або непрямих переваг під час укладення, зміни та припинення трудового договору залежно від походження, соціального й майнового стану, расової та національної приналежності, статі, мови, політичних поглядів, релігійних переконань, членства у професійній спілці чи іншому об'єднанні громадян, роду і характеру занять, місця проживання (ст. 22 КЗпП).

Заборона щодо дискримінації за ознаками сімейного стану міститься у ст. 184 КЗпП, яка закріплює заборону відмовляти жінкам під час прийняття на роботу з мотивів вагітності або наявності в них дітей, яка відбита й у Законі України «Про забезпечення рівних прав та можливостей жінок і чоловіків» [11], яким установлено законодавчу заборону дискримінаціі за статевою ознакою та який містить окрему ст. 17, присвячену питанням забезпечення рівних прав та можливостей жінок і чоловіків у праці 
й одержанні винагороди за неї. Також необхідно згадати проєкт Трудового кодексу України [12], у ст. 3 якого передбачено заборону дискримінаціï у сфері праці, зокрема забороняється будь-яка дискримінація у сфері праці, порушення принципу рівності прав і можливостей, пряме або непряме обмеження прав працівників залежно від раси, кольору шкіри, політичних, релігійних та інших переконань, статі, етнічного, соціального й іноземного походження, віку, стану здоров'я, інвалідності, підозри чи наявності захворювання на ВІЛ/СНІД, сімейного та майнового стану, сімейних обов'язків, місця проживання, членства у професійній спілці чи іншому об'єднанні громадян, участі у страйку, звернення або наміру звернення до суду чи інших органів за захистом своїх прав або надання підтримки іншим працівникам у захисті їніх прав, за мовними або іншими ознаками, не пов'язаними 3 характером роботи або умовами ii виконання. Водночас не вважаються дискримінацією у сфері праці передбачені цим Кодексом та законами обмеження прав і можливостей або надання переваг працівникам залежно від певних видів робіт, які стосуються віку, рівня освіти, стану здоров'я, статі, інших відповідних обставин, а також необхідності посиленого соціального та правового захисту деяких категорій осіб. Законами і статутами господарських товариств (крім акціонерних), виробничих кооперативів, фермерських господарств, громадських організацій можуть встановлюватися переваги для їх засновників (учасників) і членів під час надання роботи, переведення на іншу роботу та залишення на роботі в разі вивільнення.

Використання

законодавцем у ст. 22 чинного КЗпП слів «пряме(-их) або непряме(-их) обмеження (переваг)» свідчить про існування двох видів дискримінації: (1) прямої та (2) непрямої. Перша наявна, коли нерівне ставлення виникає внаслідок прямого застосування законів, правил чи практики, які виражаються в явно відмінному ставленні за однією конкретною ознакою. Як приклад такої дискримінації можна назвати обмеження рівності можливостей за ознаками віку, статті, національної приналежності тощо. Друга пов'язана 3 тими випадками, правилами та практикою, які на перший погляд здаються нейтральними, але на практиці призводять до невигідних ситуацій для тих осіб, на яких поширюється така дискримінація. Наприклад, установлення вимоги знання мови даної країни під час прийому на роботу, для виконання якої немає особливої потреби такого знання (для виконання роботи двірника, наприклад) є проявом дискримінації щодо працівників-іноземців, представників національних меншин. Натомість установлення тих чи інших обмежень або переваг уважається допустимим, коли висунення певних вимог є об'єктивно обгрунтованим, а засоби для досягнення мети правильно підібрані та $є$ необхідними, тобто мають ознаки «ділової необхідності».

У процесі дослідження даної проблематики варто зупинитися на питанні дискримінації за ознаками статті. Сьогодні у світі набуває поширення гендерний рух, представники та прихильники якого стверджують, що «диференціація праці розвиває у жінок почуття непов-

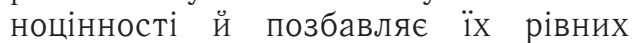
можливостей у доступі до джерел існування» [13, с. 104]. Практика європейського судочинства також свідчить, що європейська спільнота нині віддає перевагу зрівнялівці жінок із чоловіками у сфері праці. Так, наприклад, у рішенні у справі "Commission V. French Republic" Суд Європейського Союзу постановив, що заборона на роботу в нічний час для жінок порушує принцип однакового ставлення до жінок і чоловіків [14, с. 15]. Ідеї гендерної рівності 
планується втілити і в новому Трудовому кодексі України, ст. 2 якого однією із засад правового регулювання трудових та пов'язаних із ними відносин проголошує гендерну рівність. Окремі спроби провести зрівнялівку чоловіка та жінки у трудових відносинах простежуються й в інших нормах проєкту. Такий висновок стає очевидним, якщо порівняти норми ст. 175 чинного КЗпП та ст. 291 проєкту, у яких ідеться про важливу юридичну гарантію - обмеження роботи жінок у нічний час. Згідно із чинним КЗпП дія відповідної статті поширюється на всі категорії працюючих жінок, тоді як у проєкті дана гарантія істотно знижується, оскільки обмеження полягає лише в обов'язку отримання згоди від жінок, які мають дітей до 14-ти років або дітей-інвалідів, на залучення їх до даного виду робіт. Тобто всі інші категорії працюючих жінок, які не підпадають під дію цієї норми, зможуть залучатись до роботи в нічний час безперешкодно, зокрема й вагітні жінки.

Під час вирішення питання про нормативне закріплення переваг для жінок у сфері праці порівняно із чоловіками необхідно виходити $з$ того, що $є$ професії, роботи, умови діяльності, які шкідливі не просто для жіночого організму, а для їхньої репродуктивної функції, отже, і для здоров'я майбутніх дітей. Тому слушно зазначає щодо цього В. Венедиктова: «Зрівняння жінки із чоловіком в суспільному виробництві зовсім не означає, що жінка повинна виконувати важку „чоловічу» роботу”» [15, с. 132]. Дану позицію зайняли свого часу й учасники 7-го Європейського конгресу із трудового права та права соціального забезпечення, що проходив у місті Стокгольм 6 вересня 2002 р., які визнали, що встановлення вимог виконання роботи особою певної статі допустимо в інтересах безпеки самих жінок, що включає обмеження застосування жіночої праці на підземних роботах, нічної праці тощо. Було зазначено як негативний прояв тенденції законодавства тих країн Європейського Союзу, які стали на шлях поступового скорочення таких робіт, де забороняється й обмежується застосування праці жінок [16].

Ми цілком поділяємо даний погляд на проблему дискримінації за ознаками статі, у розв'язанні якої, на нашу думку, варто відмежовувати випадки, коли жінок усувають від певних видів робіт або обмежують доступ до них для збереження їхнього здоров'я, зменшення ризику захворювань майбутніх дітей, від тих ситуацій, коли можуть ставитися перешкоди або взагалі унеможливлюватись певними способами просування жінок по службі, зменшуватись розмір заробітку, у зв'язку з тим, що працівником є жінка. Така позиція закріплена в Законі Україні «Про забезпечення рівних прав та можливостей жінок і чоловіків», у ст. 6 якого зазначено, що не вважається дискримінацією за ознакою статті соціальний захист жінок під час вагітності, пологів та грудного вигодовування дитини, а також особливі вимоги щодо охорони праці жінок і чоловіків, пов'язані з охороною їхнього репродуктивного здоров'я.

Висновки. У підсумку можемо сформулювати висновок, що проблема боротьби із проявами трудової дискримінації, особливо в умовах ринкової економіки, є досить актуальною та важливою, що вимагає особливої уваги до забезпечення ефективного й дієвого механізму реалізації законодавства про заборону дискримінації у царині праці. Вітчизняний законодавець упевнено налаштований вести активну боротьбу із проявами будьякої дискримінації у сфері праці. Про це свідчить, зокрема, ратифікація Верховною Радою України основних міжнародних нормативних документів із даного питання, а також ухвалення спеціального Закону, одним з основних завдань якого $€$ забезпечення ліквідації дискримінації за 
ознакою статті. У свою чергу, ті прогалини, які й досі мають місце в чинному трудовому законодавстві щодо забезпечення ефективної боротьби із трудовою дискримінацією, повинен заповнити новий Трудовий кодекс України, спеціальні статті якого сформульовані з урахуванням міжнародно-правових стандартів.

У статті досліджено питання заборони дискримінацї, що виникають у сфері реалізації права на працю. Зазначено, шо усунення проявів дискримінаціі у трудових відносинах є одним із важливих та першочергових пріоритетів діяльності міжнародних організацій, які з метою вирішення даної проблеми ухвалили низку нормативно-правових документів. Наголошено, що прагнення України до євроінтеграиіï зобов'язує нашу державу забезпечити відповідність національного законодавства міжнародним стандартам, зокрема і стандартам рівності у трудових правовідносинах. Зазначено, що Україна вже взяла на себе зобов'язання боротися із проявами дискримінації у сфері праці, коли ратифікувала основоположні міжнародно-правові документи із цього питання.

Акцентовано увагу, щзо нині в Україні все частішими є прояви дискримінаціï у трудових та тісно пов'язаних із ним відносинах. Так, наслідками дискримінаційних дій роботодавців є порушення прав працівників, зниження рівня зайнятості окремих їх категорій. Тому проблема боротьби із проявами трудової дискримінації, особливо в умовах ринкової економіки, $\epsilon$ досить актуальною та важливою, що вимагає особливої уваги до забезпечення ефективного й дієвого механізму реалізації законодавства про заборону дискримінації в иарині праці. Вітчизняний законодавець упевнено налаштований вести активну боротьбу із проявами будь-якої дискримінації у сфері праці. Про це свіочить, зокрема, ратифікація Верховною Радою України основних міжнародних нормативних документів із даного питання, а також ухвалення спеціального Закону, одним з основних завдань якого є забезпечення ліквідаціі дискримінації за ознакою статті. У свою чергу, ті прогалини, які й досі мають місие в чинному трудовому законодавстві щзодо забезпечення ефективної боротьби із трудовою дискримінацією, повинен заповнити новий Трудовий кодекс України, спеціальні статmі якого сформульовані з урахуванням міннародно-правових стандартів.

Ключові слова: працівник, роботодавець, трудові відносини, дискримінація, гендерна рівність, національне законодавство, міжнародні документи.

\section{Shadei M. On the prohibition of discrimination in the field of work}

The article examines the issue of prohibition of discrimination arising in the exercise of the right to work. It is noted that the elimination of discrimination in labor relations is one of the important and priority priorities of international organizations, which in order to address this issue have adopted a number of legal documents. It is emphasized that Ukraine's desire for European integration obliges our state to ensure compliance of national legislation with international standards, including standards of equality in labor relations. It is noted that Ukraine has already committed itself to combating discrimination in the field of labor by ratifying the basic international legal instruments on this issue.

It is emphasized that today in Ukraine there are more and more manifestations of discrimination in labor and closely related relations. Thus, the consequences of discriminatory 
actions of employers are a violation of workers' rights, reducing the level of employment of certain categories. Therefore, the problem of combating manifestations of labor discrimination, especially in a market economy, is very relevant and important, which requires special attention to ensure an effective and efficient mechanism for implementing legislation prohibiting discrimination in the field of labor. The domestic legislator is confidently determined to actively combat any manifestations of discrimination in the field of labor. This is evidenced, in particular, by the ratification by the Verkhovna Rada of Ukraine of the main international normative documents on this issue, as well as the adoption of a special law, one of the main tasks of which is to ensure the elimination of discrimination on the basis of article. In turn, the gaps that still exist in the current labor legislation to ensure the effective fight against labor discrimination should be filled by the new Labor Code of Ukraine, special articles of which are formulated in accordance with international legal standards.

Key words: employee, employer, labor relations, discrimination, gender equality, national legislation, international documents.

\section{Література}

1. Загальна декларащія прав людини від 10 грудня 1948 р. Офіційний вісник України. 2008. № 93. Ст. 3103.

2. Ярошенко О. Щодо дискримінації в реалізації права на пращю. Право України. 2000. № 7. С. 51-54.

3. Міжнародний пакт про економічні, соціальні і культурні права від 16 грудня 1966 р. Вісник Конституиійного Суду України. 2006. № 4.

4. Конвениія МОП № 111 про дискримінацію в галузі праці і занять 1958 р.
Відомості Верховної Ради Української Радянської Соціалістичної Республіки. 1961. № 46. Cm. 513.

5. Європейська соціальна хартія (переглянута) від 3 травня 1996 р. Відомості Верховної Ради України. 2007. № 51 .

6. Гузь О. Дискримінація як форма порушення прав людини. Форум права. 2012. № 2. C. 166-169.

7. Black H. Black's Law Dictionary Special Deluxe. 1th ed. M.A. St. Paul Minn. 1979. P. 1511-1512.

8. Nuse B., Dukelow D. The Dictionary of Canadian Law. 1991. P. 237.

9. Anglim C. Labor, Employment, and the Law. A Dictionary. ABC-CLIO. Santa Barbara, California. 1997. P. 146-148.

10. Кодекс Законів про працю України від 10 грудня 1971 р. Відомості Верховної Ради Української Радянської Соціалістичної Республіки. 1971. Дод. до № $50 . \mathrm{Cm}$. 375 .

11. Про забезпечення рівних прав та можливостей жінок $і$ чоловіків: Закон України від 8 вересня 2005 р. № 2866-IV. Відомості Верховної Ради України. 2005. № $52 . \mathrm{Cm} .561$.

12. Проєкт Трудового кодексу України від 20 mравня 2015 p. № 1658. URL: http: / / w1.c1.rada.gov.ua/pls / zweb2 / webproc 4_1?pF3511=53221.

13. Никольский В. Трудовое право Российской Федеращии : учебно-методический комплекс. Москва : Изд. центр ЕАОИ. 2008. 404 c.

14. Трудове право ЄC: навчальнии посібник. Київ: Iнститут міжнародних відносин КНУ ім. Т. Шевченка, 2004. $185 \mathrm{c}$

15. Венедиктова В. Забезпечення фактичної рівності при реалізаціі права на пращюю. Право і безпека. 2004. № № 3-2. С. 133-134.

16. Горбачева Ж. Запрет дискриминациии по признаку пола в трудовых отношениях в странах Европейского Союза. Права женщин в России: законодательство и практика. 2002. № № 3-4 (14). URL: http:// www. womnet.ru/prava/2002/nomer_14/5.htm. 